Sergii V. Telyma, $\mathrm{PhD}$, Senior Research Associate

ORCID ID 0000-0003-0109-0696e-mail: telymaser@gmail.com

Institute of Hydromechanics of National Academy of Sciences of Ukraine, Kyiv, Ukraine

\title{
CALCULATIONS OF THE SYSTEMATIC VERTICAL DRAINAGE UNDER PROTECTION OF THE IRRIGATED LANDS AND THE BUILT-UP TERRITORIES FROM THE GROUND WATERS SUBMERGENCE
}

\begin{abstract}
The methodic of the solution of the problem of the transient flow in multilayer heterogeneous in cross section aquifer at modeling of the vertical drainage work with different boundary conditions on the contour of the drainage well is proposed. The numerical aspects of the solution of the given problem and the example of solution the methodic task for scheme of the three-layer aquifer at the constant drawdown of the ground and underground waters on the well contour are considered.
\end{abstract}

Keywords: analytical solution; transient flow; numerical algorithm; vertical drainage; multilayer aquifer

\section{Introduction}

It is known that the vertical drainage is widely used in solving the problems of protection against the flooding by the groundwaters of the irrigated lands and the built-up areas. In most cases it is necessary to consider the transient filtration in a heterogeneous multilayer aquifer with an interconnection between the main aquifers through the weakly permeable layers of soils with low filtration properties [1-6].

In this work the problem of transient filtration in a three-layer aquifer with a constant drawdown $S_{0}$ in the main aquifers consisting of two aquifers of ground and underground waters separated by a weakly permeable separation layer is considered (Fig. 1).

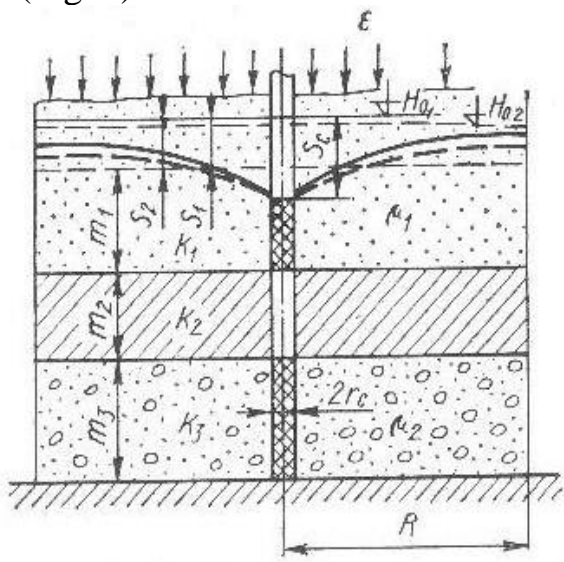

This problem was investigated by many authors for different calculative schemes and boundary conditions. Some aspects of the given problem were considered for example in the works [3-6]. In the given event a rigid filtration regime in separate layer is adopted. The algorithm and the corresponding computer program are developed which allow to simplify the solution of the abovementioned problems as the analytical solutions are more complex and difficult. The proposed methodic has a practical significance at decision the problems of the ecology and for evaluation

Fig. 1 - Calculative scheme for vertical drainage in three-layer and planning water resources. 


\section{The formulation and numerical-analytic solution of the given problem}

For given case the transient radial filtration in this system is written by the following system of differential equations:

$$
\begin{gathered}
a_{1}\left(\frac{\partial^{2} S_{1}}{\partial r^{2}}+\frac{1}{r} \frac{\partial S_{1}}{\partial r}\right)-b_{1}\left(S_{1}-S_{2}\right)+\bar{\varepsilon}=\frac{\partial S_{1}}{\partial t} \\
a_{2}\left(\frac{\partial^{2} S_{2}}{\partial r^{2}}+\frac{1}{r} \frac{\partial S_{2}}{\partial r}\right)+b_{2}\left(S_{1}-S_{2}\right)=\frac{\partial S_{2}}{\partial t}
\end{gathered}
$$

where $\quad a_{1}=\frac{T_{1}}{\mu_{1}} ; \quad a_{2}=\frac{T_{3}}{\mu_{2}} ; \quad b_{1}=\frac{k_{2}}{\mu_{2} m_{2}} ; \quad b_{2}=\frac{k_{2}}{\mu_{2} m_{2}} ; \quad \bar{\varepsilon}=\frac{\varepsilon}{\mu_{1}} ;$ $R=\frac{\sigma}{\sqrt{\pi}}=0.56 \sigma ; T_{1}=k_{1} m_{1} ; T_{3}=k_{3} m_{3}$

$S_{i}(r, t)=H_{0_{i}}-H_{i}(r, t)-$ the drawdowns of levels of ground and underground waters respectively in the first and second layers; $H_{0_{i}}$ and $H_{i}(r, t)$-water levels according to the start of drainage and in the process of water withdrawal; $k_{1}, k_{2}, k_{3}, \mu_{1}, \mu_{2}, m_{1}, m_{2}, m_{3}$ - respectively the coefficients of filtration, storativity and the thickness of the main waterbearing layers; $\varepsilon$ - average intensity of infiltration supply; $\sigma$-the distance between the drainage wells; $i=1.2$.

The system of equations (1) is solved under the following initial and boundary conditions on the outer contour of the aquifer:

$$
\begin{gathered}
t=0, \quad S_{i}=0 \\
t>0, \quad r=R, \quad \frac{\partial S_{i}}{\partial r}=0
\end{gathered}
$$

and the boundary conditions on the contour of the well with radius $r_{0}$ for different variants, namely: water withdrawal with constant drawdown in both layers; water withdrawal at constant drawdowns in the lower layer and water withdrawal with constant discharge from both layers:

$$
\begin{gathered}
t>0, \quad r=r_{0}, \quad S_{i}=S_{0} \\
t>0, \quad r=r_{0}, \quad \frac{\partial S_{i}}{\partial r}=0, \quad S_{2}=S_{0} \\
t>0, \quad r=r_{0}, \quad \frac{\partial S_{i}}{\partial r}=0, \quad 2 \pi r T_{i} \frac{\partial S_{i}}{\partial r}=-Q .
\end{gathered}
$$

Let us represent the solution relative $S_{i}$ in the following form:

$$
S_{i}=S_{i}^{\prime}(r, \infty)+S_{i}^{\prime \prime}(r, t)
$$


where the drawdown $S_{i}^{\prime}(r, \infty)$ is found as a result of the solution of system (1) with $t \rightarrow \infty\left(\partial S_{i} / \partial t\right)=0$ and the given boundary conditions; the drawdown $S_{i}^{\prime \prime}(r, t)$ is found by solving system (1) at $\bar{\varepsilon}=0$ and the boundary conditions for each of the above cases.

The solution for $S_{i}$ under the boundary conditions (3)-(4) has the following form $[1,2]$ :

$$
\begin{gathered}
S_{1}^{\prime}(r, \infty)=\frac{S_{0}(r)}{T}+\frac{T_{1}}{T} \varepsilon_{0}\left(W_{1}+W_{2}-1\right) \\
S_{2}^{\prime}(r, \infty)=\frac{S_{0}(r)}{T}+\frac{T_{3}}{T} \varepsilon_{0}\left(W_{1}+W_{2}+1\right),
\end{gathered}
$$

where $S_{0}(r)=S_{0} T-\frac{\varepsilon R^{2}}{2} \ln \frac{r}{r_{0}}+\frac{\varepsilon}{4}\left(r^{2}-r_{0}^{2}\right), \quad \varepsilon_{0}=\varepsilon \frac{m_{2}}{k_{2}} \frac{T_{3}}{T}$

$$
\begin{gathered}
W_{1}=\frac{I_{0}(c r)}{I_{1}\left(c r_{0}\right)+\frac{I_{1}(c R)}{K_{1}(c R)} K_{0}\left(c r_{0}\right)}, \quad W_{2}=\frac{K_{0}(c R)}{K_{0}\left(c r_{0}\right)+\frac{K_{1}(c R)}{I_{1}(c R)} I_{0}\left(c r_{0}\right)}, \\
T=K_{1} m_{1}+K_{3} m_{3}, \quad T_{1}=K_{1} m_{1}, \quad T_{3}=K_{3} m_{3}, \quad c=\sqrt{\frac{k_{2}}{m_{2}} \frac{T}{T_{1} T_{3}}} .
\end{gathered}
$$

Since $c r_{0}<<1$ then we can write that $I_{0}\left(c r_{0}\right) \approx 1, K_{0}\left(c r_{0}\right)=\ln \frac{1.12}{c r_{0}}$. At $r=R$ levels of ground and underground waters are calculated according to the following formulas [1]:

$$
\begin{aligned}
& S_{1}^{\prime}(R, \infty)=S_{0}-\frac{\varepsilon R^{2}}{2 T}\left(\ln \frac{R}{r_{0}}-0.5\right)-\frac{T_{3}}{T} \varepsilon_{0}\left(1-\frac{B}{\ln \frac{1.12}{c r_{0}}+A}\right) \\
& S_{2}^{\prime}(R, \infty)=S_{0}-\frac{\varepsilon}{2} \frac{R^{2}}{T}\left(\ln \frac{R}{r_{0}}-0.5\right)-\frac{T_{1}}{T} \varepsilon_{0}\left(1-\frac{B}{\ln \frac{1.12}{c r_{0}}+A}\right)
\end{aligned}
$$

where $A=\frac{K_{1}(c R)}{I_{1}(c R)}, \quad B=K_{0}(c R)+\frac{K_{1}(c R)}{I_{1}(c R)} I_{0}(c R)$

The system of equations relative to $S_{i}^{\prime \prime}$ is solved under the boundary conditions $t=0, S_{i}^{\prime \prime}=-S_{i}^{\prime}$ and $t>0, r_{0}=r_{0}, S_{i}^{\prime \prime}=0$ and condition (3).

We use Hankel's transformation relative to $S_{i}^{\prime \prime}$ in the form: 


$$
H\left[S_{i}^{\prime \prime}(r, t)\right]=\int_{r_{0}}^{R} r V_{0}(p r) S_{i}^{\prime \prime}(r, t) d r
$$

with kernel conversion

$$
V_{0}(p r)=j_{0}(p r) Y_{0}\left(p r_{0}\right)-j_{0}\left(p r_{0}\right) Y_{0}(p r)
$$

where $p$ - the roots of the characteristic equation

$$
j_{1}(p R) Y_{0}\left(p r_{0}\right)-j_{0}\left(p r_{0}\right) Y_{0}(p R)=0 \text {. }
$$

Using the relationships resulting from the properties of the function $V(p r)$, namely: $\quad V_{0}(p r) \rightarrow 0, V_{0}^{\prime}(p r)+p r V_{0}^{\prime \prime}(p r)=-p r V_{0}(p r), \quad V_{1}\left(p r_{0}\right)=2 / \pi p r_{0}$, we obtain the following: $H\left[\frac{1}{r} \frac{\partial}{\partial r}\left(r \frac{\partial S_{i}^{\prime \prime}}{\partial r}\right)\right]=\int_{r_{0}}^{R} V_{0}(p r) \frac{\partial}{\partial r}\left(r \frac{\partial S_{i}^{\prime \prime}}{\partial r}\right) d r=-p S_{i^{\prime \prime}}^{\prime \prime}$

Hence the system (1) can be written as:

$$
\frac{d S_{1 *}^{\prime \prime}}{d t}=\alpha S_{1 *}^{\prime \prime}+b_{1} S_{2 *}^{\prime \prime}, \quad \frac{d S_{2 *}^{\prime \prime}}{d t}=\beta S_{2 *}^{\prime \prime}+b_{2} S_{1 *}^{\prime \prime}
$$

where $\alpha=-a_{1} p^{2}-b_{1}, \quad \beta=-a_{2} p^{2}-b_{2}$.

With $t=0$ we have that

$$
S_{i *}^{\prime \prime}=-\int_{r_{0}}^{R} r S_{i}^{\prime} V_{0}(p r) d r=\bar{S}_{i}^{\prime}
$$

Solving the system (13) we find:

$$
\begin{gathered}
S_{1}^{\prime \prime}(p, t)=S_{1 *}^{\prime \prime}=\frac{\bar{S}_{1}^{\prime}\left(\lambda_{2}-\alpha\right)-b_{1} \bar{S}_{2}^{\prime}}{\lambda_{2}-\lambda_{1}} e^{\lambda_{1} t}+\frac{\bar{S}_{1}^{\prime}\left(\alpha-\lambda_{1}\right)+b_{1} \bar{S}_{1}^{\prime}}{\lambda_{2}-\lambda_{1}} e^{\lambda_{2} t} \\
S_{2}^{\prime \prime}(p, t)=S_{2 *}^{\prime \prime}=\frac{\bar{S}_{2}^{\prime}\left(\lambda_{2}-b_{2}\right)-b_{1} \bar{S}_{1}^{\prime}}{\lambda_{2}-\lambda_{1}} e^{\lambda_{1} t}+\frac{\bar{S}_{2}^{\prime}\left(b_{2}-\lambda_{1}\right)+\beta \bar{S}_{1}^{\prime}}{\lambda_{2}-\lambda_{1}} e^{\lambda_{2} t}
\end{gathered}
$$

where

$$
\lambda_{1}=\frac{\alpha+\beta}{2}+\sqrt{\left(\frac{\alpha-\beta}{2}\right)^{2}+b_{1} b_{2}} ; \quad \lambda_{2}=\frac{\alpha+\beta}{2}-\sqrt{\left(\frac{\alpha-\beta}{2}\right)^{2}+b_{1} b_{2}} .
$$

The transition from the images of function $S_{i}^{\prime \prime}(p, t)$ to their originals $S_{i}(r, t)$ is performed according to the following formula: 


$$
S_{i}^{\prime \prime}(r, t)=\frac{\pi^{2}}{2} \sum_{n=1}^{\infty} \frac{p_{n}^{2} j_{1}^{2}\left(p_{n} R\right) V_{0}\left(p_{n} r\right)}{j_{0}^{2}\left(p_{n} r_{0}\right)-j_{1}^{2}\left(p_{n} R\right)} S_{i}^{\prime \prime}\left(p_{n}, t\right) .
$$

Quite a difficult problem in determining the drawdowns $S_{1}^{\prime \prime}\left(p_{n}, t\right)$ and $S_{2}^{\prime \prime}\left(p_{n}, t\right)$ is finding the quantities $\bar{S}_{1}^{\prime}$ and $\bar{S}_{2}^{\prime}$ by formula (15). In general the expressions relative to $\bar{S}_{1}^{\prime}$ and $\bar{S}_{2}^{\prime}$ can be rewritten in (8) in the following form:

$$
\overline{S_{i}^{\prime}}=\alpha r^{2}+\beta \ln \frac{r}{r_{0}}+\gamma_{1} I_{0}(c r)+\delta_{i} K_{0}(c r)+C_{i},
$$

where $\quad \alpha=\frac{\varepsilon}{4 T}, \quad \beta=-\frac{\varepsilon R^{2}}{2 T}, \quad \gamma_{1}=\delta_{1} A, \quad \gamma_{2}=\delta_{2} A, \quad \delta_{1}=\frac{T_{3} \varepsilon_{0}}{T\left(A+\ln \frac{1.12}{c r_{0}}\right)}$, $\delta_{2}=-\frac{T_{1} \varepsilon_{0}}{T\left(A+\ln \frac{1.12}{c r_{0}}\right)}, C_{1}=S_{0}-\frac{T_{3}}{T} \varepsilon_{0}, C_{2}=S_{0}+\frac{T_{1}}{T} \varepsilon_{0}, A=2 \pi \Delta f$.

Substituting the value $\overline{S_{i}^{\prime}}$ into (15) we obtain that:

$$
\begin{aligned}
& \bar{S}_{i}^{\prime}=-\alpha \int_{r_{0}}^{R} r^{3} V_{0}(p r) d r-\beta \int_{r_{0}}^{R} r \ln r V_{0}(p r) d r-\gamma_{i} \int_{r_{0}}^{R} I_{0}(c r) V_{0}(p r) d r- \\
& -\delta_{i} \int_{r_{0}}^{R} r K_{0}(c r) V_{0}(p r) d r-\int_{r_{0}}^{R} C_{i} r V_{0}(p r) d r
\end{aligned}
$$

where the function $V_{0}(p r)$ is in accordance with formula (11). Then the first integral can be represented for example in the following:

$$
-\alpha \int_{r_{0}}^{R} r^{3} V_{0}(p r) d r=\alpha \theta \int_{r_{0}}^{R} r^{3} j_{0}(p r) d r+\alpha w \int_{r_{0}}^{R} r^{3} Y_{0}(p r) d r,
$$

where $\theta=-Y_{0}\left(p r_{0}\right)=0,64 \ln \frac{1,12}{p r_{0}}, \quad \omega=j_{0}\left(p r_{0}\right) \approx 1$.

In the same way we can write the other integrals in equation (20). As a result of computing the integrals we obtain the following formula for determination $\bar{S}_{i}^{\prime}$ :

$$
\bar{S}_{i}^{\prime}=\frac{1}{P^{2}}\left(\alpha R^{2} \varphi_{1}+\beta \varphi_{2}+\gamma_{i} \varphi_{3}+\delta_{i} \varphi_{4}+C_{i} \varphi_{5}\right)
$$

where $\varphi_{i}=\theta \varphi_{i}^{\prime}+\omega \varphi_{i}^{\prime \prime} \quad(i=\overline{1.5})$ 


$$
\begin{aligned}
& \varphi_{1}^{\prime}=\mu j_{1}(\mu)-2 j_{2}(\mu) ; \quad \varphi_{1}^{\prime \prime}=\mu Y_{1}(\mu)-2 Y_{2}(\mu)-\frac{8}{\pi \mu^{2}} \\
& \varphi_{2}^{\prime}=\mu \ln \frac{R}{r_{0}} j_{1}(p r)+j_{0}(\mu)-1 ; \quad \varphi_{2}^{\prime \prime}=\mu \ln \frac{R}{r_{0}} Y_{1}(\mu)+Y_{0}(\mu)+0,64 / p_{n} \cdot \frac{1.12}{\mu r_{0}} \\
& \varphi_{3}^{\prime}=\frac{\bar{c} I_{1}(\bar{c}) j_{0}(\mu)+\mu I_{0}(\bar{c}) j_{1}(\mu)}{1+\left(\frac{\bar{c}}{\mu}\right)^{2}} ; \quad \varphi_{3}^{\prime \prime}=\frac{\bar{c} I(\bar{c}) Y(\mu)+\mu I_{0}(\bar{c}) Y_{1}(\mu)+\frac{2}{\pi}}{1+\left(\frac{\bar{c}}{\mu}\right)^{2}} \\
& \varphi_{4}^{\prime}=\frac{1-\bar{c} K_{1}(\bar{c}) j_{0}(\mu)+\mu K_{0}(\bar{c}) j_{1}(\mu)}{1+\left(\frac{\bar{c}}{\mu}\right)^{2}} ; \quad \varphi_{4}^{\prime \prime}=\frac{0.64 \ln \frac{\mu}{\bar{c}}-\bar{c} K_{1}(\bar{c}) Y_{0}(\mu)+\mu K_{0}(\bar{c}) Y_{1}(\mu)}{1+\left(\frac{\bar{c}}{\mu}\right)^{2}} ; \\
& \varphi_{5}^{\prime}=\mu j_{1}(\mu) ; \quad \varphi_{5}^{\prime \prime}=\mu Y_{1}(\mu)+\frac{2}{\pi} ; \quad \mu=p R, \bar{c}=c R, \quad \bar{r}=\frac{r}{R} \& \overline{r_{0}}=\frac{r_{0}}{R} .
\end{aligned}
$$

The calculated on the computer values of the parameters $\varphi_{i}^{\prime}, \varphi_{i}^{\prime \prime}$ and $\theta$ for various values $\mu_{i}, \bar{r}_{0}$ and $\bar{c}$ were tabulated and summarized in the corresponding tables.

$$
\text { When } \bar{c}>3 \text { we may take } \varphi_{4}^{\prime}=\frac{1}{1+\left(\frac{\bar{c}}{\mu}\right)^{2}} ; \quad \varphi_{4}^{\prime \prime}=\frac{0.64 \ln \frac{\mu}{\bar{c}}}{1+\left(\frac{\bar{c}}{\mu}\right)^{2}} \text {. }
$$

Finally the formulas relatively drawdowns $S_{1}(r, t)$ and $S_{2}(r, t)$ have the following form:

$$
S_{i}(r, t)=S_{i}^{\prime}+\frac{\pi^{2}}{2} \sum_{n=1}^{\infty} P\left(\mu_{n}\right) V_{0}(\mu \bar{r}) \overline{S_{i}^{\prime \prime}}\left(\mu_{n}, t\right)
$$

where $P\left(\mu_{n}\right) \approx \frac{j_{1}^{2}\left(\mu_{n}\right)}{1-j_{1}^{2}\left(\mu_{n}\right)}-$ tabulated function.

The total withdrawal from the well $Q$ consists of the flow from the upper and lower aquifers. Using the known dependence of the type:

$$
Q_{i}=-\left.2 \pi r T_{i} \frac{\partial S_{i}}{\partial r}\right|_{r=r_{0}}
$$

we get the relations for $Q_{1}(t)$ and $Q_{2}(t)$ : 


$$
\begin{gathered}
Q_{1}(t)=Q_{1}^{\prime}+2 \pi^{2} T_{1} \sum_{n=1}^{\infty} P\left(\mu_{n}\right) S_{1}^{\prime \prime}\left(\mu_{n}, t\right) \\
Q_{2}(t)=Q_{2}^{\prime}+2 \pi^{2} T_{3} \sum_{n=1}^{\infty} P\left(\mu_{n}\right) S_{2}^{\prime \prime}\left(\mu_{n}, t\right),
\end{gathered}
$$

where $Q_{1}^{\prime}$ and $Q_{2}^{\prime}$ - the discharges at the stationary filtration regime $(t \rightarrow \infty)$ :

$$
\begin{gathered}
Q_{1}^{\prime}=\frac{\pi \varepsilon T_{1}}{T}\left(R^{2}-r_{0}^{2}\right)+\frac{2 \pi T_{1} T_{3} \varepsilon_{0}}{T} G \\
Q_{2}^{\prime}=\frac{\pi \varepsilon T_{3}}{T}\left(R^{2}-r_{0}^{2}\right)-\frac{2 \pi T_{1} T_{3} \varepsilon_{0}}{T} G \\
G=\frac{1}{c r_{0}\left(\ln \frac{1.12}{c r_{0}}+A\right)}, Q^{\prime}=Q_{1}^{\prime}+Q_{2}^{\prime}=\pi \varepsilon\left(R^{2}-r_{0}^{2}\right) .
\end{gathered}
$$

For engineering calculations the formulas (25)-(26) can be simplified to the following form:

$$
Q_{1}(t)=Q_{1}^{\prime}+Q_{1}^{0} e^{\lambda_{n} t} ; \quad Q_{2}(t)=Q_{2}^{\prime}+Q_{2}^{0} e^{\lambda_{n} t}
$$

where $Q_{i}^{0}=\frac{4 T_{i} S_{i}(R)}{Y_{0}\left(\mu_{1}\right)+0.64 I_{0}\left(\mu_{1}\right) \ln \frac{1.12 R}{\mu_{1} r_{0}}}, \quad(i=1.2)$

and the drawdowns $S_{i}(R)$ are found by the formulas (9).

For verification of the developed numerical algorithm the methodic example of the filtration in three-layer aquifer where the drainage well is working with a constant drawdown $S_{0}=5.0 \mathrm{~m}$ in both layers in the center of the round filtration domain with radius $R=500.0 \mathrm{~m}$ was considered (Fig. 1). The thickness of the layers is respectively $m_{1}=m_{3}=10 \mathrm{~m}, m_{2}=5 \mathrm{~m}$; filtration coefficients $k_{1}=5.0 \mathrm{~m} /$ day, $k_{2}=0.01 \mathrm{~m} /$ day, $k_{3}=20 \mathrm{~m} /$ day; storativity coefficients $\mu_{1}=0.1, \mu_{2}=0.002$ and the value of the infiltration rate $\varepsilon=0.001 \mathrm{~m} /$ day. The given scheme corresponds one of the systematic plane drainage where the wells are situated on the distance $\sigma=R \sqrt{ }=885.0 \mathrm{~m}$ one from other.

The results of the numerical calculations of the drawdowns $S_{1}$ and $S_{2}$ according to the formulas:

$$
S_{i}(r, t)=S_{i}^{\prime}+\frac{\pi^{2}}{2} \sum P\left(\mu_{n}\right) V_{0}(\mu \bar{r}) \overline{S_{i}^{\prime \prime}}\left(\mu_{n}, t\right), \quad(i=1.2)
$$

at $R=500 \mathrm{~m}$ for different times are presented on the Fig. 2 . 


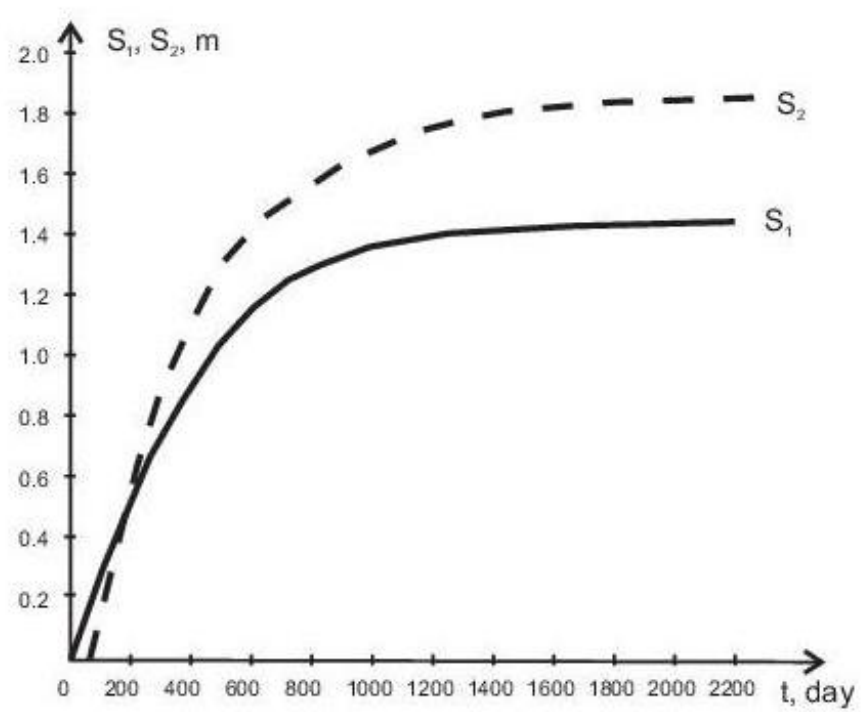

Fig. 2 - Calculative graphs of the drawdowns in three-layer aquifer

We can see from the obtained graphs that at times 2000 days and more the filtration regime close to steady one in both aquifers and the steady regime is reached at time 5000 days after pumping begins. At this the value of the withdrawal from the first and second layers $Q_{1}(t)$ and $Q_{2}(t), Q(t)=Q_{1}(t)+Q_{2}(t)$ calculated by the following formulas:

$$
\begin{aligned}
& Q_{1}(t)=\frac{\pi \varepsilon T_{1}}{T}\left(R^{2}-r_{0}^{2}\right)+\frac{2 \pi T_{1} T_{3} \varepsilon_{0}}{T} G+2 \pi^{2} T_{1} \sum_{n=1}^{m} P\left(\mu_{n}\right) S_{1}^{\prime \prime}\left(\mu_{n}, t\right) \\
& Q_{2}(t)=\frac{\pi \varepsilon T_{3}}{T}\left(R^{2}-r_{0}^{2}\right)-\frac{2 \pi T_{1} T_{3} \varepsilon_{0}}{T} G+2 \pi^{2} T_{3} \sum_{n=1}^{m} P\left(\mu_{n}\right) S_{2}^{\prime \prime}\left(\mu_{n}, t\right)
\end{aligned}
$$

and for the values of the upper bound of the sum $m=20$ equal accordingly 174.52, 610.87 and $785.40 \mathrm{~m}^{3} /$ day $\left(r=R=500 \mathrm{~m}\left(\bar{r}_{0}=1\right)\right.$.

On the other hand the steady filtration regime is possible if the value of infiltration over the all filtration domain must to be equal or more of the sum of the withdrawal from two aquifers. Using the formula (27) we get $Q^{\prime}=785.00 \mathrm{~m}^{3} /$ day. So the slight error between given and calculative values of the inflow and withdrawal is explained by the errors of numerical calculations on the computer. In that way the results of the example solution show that the developed methodic allows to solve the problems of the transient flow in multilayered aquifers at the exploitation of the vertical drainage with enough for practical aims accuracy.

For simplification of the solutions of the practical problems in some cases when we need to solve the class of the similar tasks the values of the constituents of the formula:

$$
S_{i}(r, t)=S_{i}^{\prime}+\frac{\pi^{2}}{2} \sum_{n=1}^{m} P\left(\mu_{n}\right) V_{0}(\mu \bar{r}) \overline{S_{i}^{\prime \prime}}\left(\mu_{n}, t\right),
$$


namely: $P\left(\mu_{n}\right) V_{0}(\mu \bar{r}) \bar{S}_{i}^{\prime \prime}\left(\mu_{n}, t\right)$ for $m=1,2,5,20$ and values $t=1,2,50,100,150$, 200, 500, 1000, 5000 days are presented in the Table 1.

Table 1 - Numerical values of the constituents of the series to determine the drawdowns $S_{2} \quad i \quad S_{1}$

\begin{tabular}{|l|l|l|l|l|l|l|}
\hline$t$, day & $n=1$ & $n=2$ & $n=3$ & $n=4$ & $n=5$ & $n=6$ \\
\hline \multicolumn{7}{|c|}{$S_{2}, m$} \\
\hline 20 & $-4.270 \cdot 10^{-1}$ & $3.141 \cdot 10^{-3}$ & $-1.181 \cdot 10^{-4}$ & $3.821 \cdot 10^{-6}$ & $-7.5 \cdot 10^{-8}$ & $8.1 \cdot 10^{-10}$ \\
50 & $-3.916 \cdot 10^{-1}$ & $6.760 \cdot 10^{-4}$ & $-2.673 \cdot 10^{-6}$ & $2.852 \cdot 10^{-8}$ & $-7 \cdot 10^{-13}$ & \\
100 & $-3.388 \cdot 10^{-1}$ & $5.225 \cdot 10^{-5}$ & $-4.841 \cdot 10^{-8}$ & $1.7 \cdot 10^{-14}$ & & \\
150 & $-2.932 \cdot 10^{-1}$ & $4.038 \cdot 10^{-6}$ & $-8.768 \cdot 10^{-12}$ & & & \\
200 & $-2.537 \cdot 10^{-1}$ & $3.120 \cdot 10^{-7}$ & $-1.588 \cdot 10^{-14}$ & & & \\
500 & $-1.065 \cdot 10^{-1}$ & $6.651 \cdot 10^{-13}$ & & & \\
1000 & $-2.507 \cdot 10^{-1}$ & & & & \\
5000 & $-2.360 \cdot 10^{-7}$ & & & & \\
\hline \multicolumn{7}{|c|}{$S_{1}, m$} \\
\hline 20 & $-3.189 \cdot 10^{-1}$ & $1.850 \cdot 10^{-2}$ & $-1.938 \cdot 10^{-4}$ & $1.246 \cdot 10^{-4}$ & $-4.126 \cdot 10^{-6}$ & $6.649 \cdot 10^{-8}$ \\
50 & $-2.924 \cdot 10^{-1}$ & $3.980 \cdot 10^{-3}$ & $-4.388 \cdot 10^{-5}$ & $9.302 \cdot 10^{-8}$ & $-3 \cdot 10^{-11}$ & \\
100 & $-2.530 \cdot 10^{-1}$ & $3.076 \cdot 10^{-4}$ & $-7.947 \cdot 10^{-8}$ & $5.7 \cdot 10^{-13}$ & & \\
150 & $-2.189 \cdot 10^{-1}$ & $2.378 \cdot 10^{-5}$ & $-4.439 \cdot 10^{-10}$ & & & \\
200 & $-1.894 \cdot 10^{-1}$ & $1.838 \cdot 10^{-6}$ & $-2.607 \cdot 10^{-13}$ & & & \\
500 & $-7.952 \cdot 10^{-3}$ & $3.916 \cdot 10^{-13}$ & & & \\
1000 & $-1.872 \cdot 10^{-2}$ & & & & \\
5000 & $-1.762 \cdot 10^{-7}$ & & & & \\
\hline
\end{tabular}

It is necessary to notice that to calculate the Bessel functions $I_{0}(x), I_{1}(x)$, $Y_{0}(x), Y_{1}(x), j_{0}(x), j_{1}(x), K_{0}(x), K_{1}(x)$ the representation of them in the form of series and respective subroutines were used.

In the testing of subroutines for calculating the Bessel functions the control examples were calculated the results of which coincided with given accuracy with the table values for these functions.

\section{Conclusions}

The developed numerical solution, algorithm and the computer programs for considered problem allow to investigate of the wide range of the practical problems using vertical drainage in bounded and unbounded flow domains of the multilayer aquifers. The results of the numerical solution of the methodic example shown that in practical calculations it is enough to take into account 2-3 terms of the series in formula (22) without a loss of the accuracy in calculations. In the whole the proposed methodic of numerical-analytic calculations of the vertical drainages in layered waterbearing beds may to find a wide application in solution the problems of the protection of the urban territories and the irrigated lands from the flooding and submerging by the ground waters. 


\section{REFERENCES}

1. Oleynik, A. Ya. (1978). Filtering calculations of vertical drainage. Kyiv: Naukova Dumka (in Ukrainian).

2. Oleynik, A. Ya., \& Polyakov, V. L. (1975). Calculation of vertical drainage in a threelayer formation with transient filtration. Journal "Hydromechanics", 31, 46-58 (in Ukrainian).

3. Fam Loy Vu, \& Nguen Kchoan Than. (1987). Water filtration in an axially symmetric three-layer medium. Acta Geophysica Polonica, XXXV(2), 217-230 (in English).

4. Telyma, S. V. (1994). On the inverse problem of filtration in a multilayer aquifer. Journal "Hydromechanics", 68, 57-61 (in Ukrainian).

5. Telyma, S. V., \& Oleynik, E. O. (2012). Numerical-analitic calculations of the vertical drainage in the heterogeneous waterbearing bed. "Problems Of The Water Supply, Water Overflow And Hydraulics", 18, 164-176 (in Ukrainian).

6. Polyakov, V. L. (2016). The calculation of the steady filtration to systematic drainage at the water exchange with the adjacent mediums. 'Problems Of The Water Supply, Water Overflow And Hydraulics", 27, 291-301 (in Ukrainian).

Text of the article was accepted by Editorial Team 19.07.2018

\section{С.В. Телима}

\section{РОЗРАХУНКИ СИСТЕМАТИЧНОГО ВЕРТИКАЛЬНОГО ДРЕНАЖУ ПРИ ЗАХИСТІ ВІД ПІДТОПЛЕННЯ ГРУНТОВИМИ ВОДАМИ ЗЕМЕЛЬ ЗРОШЕННЯ ТА ЗАБУДОВАНИХ ТЕРИТОРІЙ}

Анотація. Запропонована методика розв'язку задачі неусталеної фільтрації в багатошаровій неоднорідній у розрізі водоносній товщі при моделюванні роботи вертикального дренажу 3 різними граничними умовами на контурі дренажної свердловини. Розглянуто чисельні аспекти вирішення даної задачі і наведено методичний приклад розв'язку для схеми трьохшарового водоносного горизонту із заданням на контурі свердловини постійного зниження грунтових і підземних вод.

Ключові слова: аналітичне рішення; неусталена фільтрація; чисельний алгоритм; вертикальний дренаж; багатошаровий водоносний горизонт

\section{Телима Сергій Васильович}

кандидат технічних наук, старший науковий співробітник Інституту гідромеханіки НАН України

Адреса робоча: 03057 Україна, м. Київ, вул. Желябова 8/4

ORCID ID 0000-0003-0109-0696 e-mail:telymaser@gmail.com 